\title{
19. International bank settlement in China and unilateral sanctions-related disputes: sources, remedies and procedures
}

\author{
Jin Sun ${ }^{1}$
}

\section{INTRODUCTION}

This chapter aims to conduct an empirical review of the remedies and procedures for foreign unilateral sanctions-related disputes in China, including its two special administrative regions, Hong Kong and Macau. Unilateral sanctions are limited hereafter to those sanctions imposed unilaterally by the major powers like the US or $\mathrm{EU}^{2}$ for coercive offensive or defensive strategic objectives. They are not supported by United Nations Security Council (UNSC) resolutions, they are sometimes adopted contrary to provisions of specific international treaties, ${ }^{3}$ and they invariably amount to unilateral and extraterritorial sanctions. ${ }^{4}$ In the specific context of China, these unilateral and extraterritorial sanctions are considered to be unlawful foreign laws or restrictions with no judicial effect in any Chinese court, ${ }^{5}$ and they are not binding on China's government or on Chinese individuals or business entities.

This chapter will: present an overview the transnational legal orders ${ }^{6}$ of these unilateral and extraterritorial sanctions ${ }^{7}$ in Mainland China, Hong Kong and Macau - three legal jurisdictions of China with different legal traditions because of the lasting influences of the Soviet,

1 This chapter is part of the author's research project that received funding from the European Research Council under the European Union's Horizon 2020 research and innovation programme (Grant Agreement PROSANCT, 'Bombs, Banks and Sanctions', Project 716216) headed by Grégoire Mallard.

2 To be fair, the Chinese government also frequently imposes unilateral sanctions or designated restrictive measures for diplomatic purposes in dealing with disputes in foreign or domestic affairs. On China's position and practice, see the chapter by Congyan Cai in this book.

3 Such as the treaty signed in 2015 by Iran and the six major world powers (P5+1) - the Joint Comprehensive Plan of Action (JCPOA) often known as the 'Iran Deal'. P5 stands for the five Permanent Members of the UNSC. Plus 1 is Germany along with the EU.

4 Charlotte Beaucillon, 'Panorama de la pratique contemporaine des sanctions extraterritoriales' in Société française de droit international (eds.), Extraterritorialités et droit international (Pedone 2020).

5 Article 3, Law of the People's Republic of China on the Application of Foreign-Related Civil Relations [including Chinese Anti-Money Laundering (AML) law and sanctions enforcement regulations]: If the application of foreign laws will harm the public interests of the People's Republic of China, the laws of the People's Republic of China shall apply. Article 6, Penal Code of China [including AML-related crimes]: This Law shall be applicable to all crimes committed within the territory of the People's Republic of China, unless otherwise provided by law ... If one of the acts or results of a crime occurs within the territory of the People's Republic of China, it is considered as a crime within the territory of the People's Republic of China.

6 Terence C Halliday and Gregory Shaffer, 'Transnational Legal Orders' in Terence C Halliday and Gregory Shaffer (eds.), Transnational Legal Orders. Cambridge Studies in Law and Society (Cambridge University Press 2015).

7 Beaucillon (n 4). 
English and Portuguese legal systems (Section 2); summarize sources and types of related disputes in bank legal practices arising out of bank compliance with unilateral and extraterritorial sanctions on Iran, North Korea, Russia, Syria and Venezuela (Section 3); introduce a variety of judicial and non-judicial remedies and procedures with cases in Mainland China (Section 4) and Hong Kong (Section 5); and draw a conclusion about Chinese practices in the field of dispute settlement mechanisms related to unilateral and extraterritorial sanctions (Section 6).

\section{TRANSNATIONAL LEGAL ORDERS CONCERNING UNILATERAL AND EXTRATERRITORIAL SANCTIONS IN MAINLAND CHINA, HONG KONG AND MACAU}

This chapter focuses on two separate legal regimes of unilateral and extraterritorial sanctions in different legal systems, ${ }^{8}$ respectively in the US and the EU.

In the US, the unilateral sanctions regime is dominated by administrative law enforcement agencies in the executive branch in which the main remedies are found through the petition removal procedure in administrative law, while judicial review is available but often considered to be supplementary to legal practices. ${ }^{9}$

In the EU, unilateral restrictive measures, including those EU designations due to overt diplomatic pressure from other countries like the US, are generally subject to judicial review in terms of both procedure and substance, for which the remedial procedures in administrative law, although available, are not often relied on, whereas judicial review in the EU courts is often contemplated by the sanctioned entities like Iranian banks for its greater effectiveness in de-listing appeals. ${ }^{10}$

In the US, the Treasury Department's Office of Foreign Asset Control (OFAC) has been widely considered to hold absolute power over foreign sanctions, for which any relevant disputes shall be subject to remedial mechanisms in administrative law - the OFAC removal petition. In the US Federal Sentencing Guidelines ${ }^{11}$ and the Economic Sanctions Enforcement Guidelines, ${ }^{12}$ full compliance and cooperation with OFAC and the DOJ (US Department of Justice $)^{13}$ will contribute to a $25-50$ per cent reduction in fines, which is otherwise not available in judicial adjudications. This could be considered as an incentive for plea bargaining, a US legal practice of negotiating an agreement between prosecution and defence. ${ }^{14}$ It might also be taken as a token of potential tension or competition between the executive and judi-

8 Jin Sun, Gregoire Mallard and Charlotte Beaucillon, 'Judicial Remedy to Tame the Hegemon: The Legal Battle in Europe Around the Iran Deal' European Journal of International Law (under review).

9 Steptoe \& Johnson LLP, 'Federal District Court Sides with OFAC in Rare Judicial Challenge of Sanctions Violations Penalty’ (24 May 2016) <www.steptoeinternationalcomplianceblog.com/2016/05/ federal-district-court-sides-with-ofac-in-rare-judicial-challenge-of-sanctions-violations-penalty/ $>$. All web addresses were accessed on 1 December 2020.

10 For details, see Sun, Mallard and Beaucillon (n 8).

11 US Federal Sentencing Guidelines 2018 Manual Annotated: <www.ussc.gov/guidelines>.

12 Department of the Treasury, 'A Framework for OFAC Compliance Commitments' (2 May 2019) $<$ www.treasury.gov/resource-center/sanctions/Documents/framework_ofac_cc.pdf.>.

13 US Department of Justice, Criminal Division, 'Evaluation of $\bar{C}$ orporate Compliance Programs' (Updated April 2019) <www.justice.gov/criminal-fraud/page/file/937501/download>.

14 On average, less than 7 per cent of cases in the US do not accept plea bargaining but opt for judicial adjudication. For details, see statistics in Grégoire Mallard and Jin Sun, 'A Viral Process of Global 
cial branches. It is left to the choice of the defendants, which, in the case of US unilateral sanctions violations, are often global banks. The general pattern of their choices in legal defence strategy is that in US sanctions for banking violations, with the exception of a French bank, ${ }^{15}$ both US and non-US banks opt to pay millions or often billions of dollars by way of settlement in administrative law, thereby voluntarily relinquishing their procedural remedy rights in the courts of law as part of the Deferred Prosecution Agreement with OFAC or the DOJ. ${ }^{16}$ In exchange OFAC or the DOJ 'agrees to release and forever discharge' the relevant bank 'without any finding of fault'. ${ }^{17}$ This also explains other patterns in the US legal orders of sanctions enforcement. Only US entities, as shown by federal court case statistics, ${ }^{18}$ with no substantial violations but nonetheless minor fines, have sued the OFAC in the federal courts to challenge its listing decisions, because it is expected that there would be little if any reduction in potential fines from settlement. This shows there are comparative advantages in the executive branch's legal order: it is efficient, it often offers some discount for a negotiable settlement deal, it prevents any further disclosure of more sensitive details (particularly about their clients for reputational concerns) and it ends an enforcement investigation 'without any finding of fault'. That is why, as shown by the drug cartel removal cases ${ }^{19}$ as well as Turkish ministers' OFAC removal for Northeast Syria sanctions, ${ }^{20}$ US lawyers often advise their clients to file for or negotiate an OFAC removal first, before looking for a remedy in the judicial branch.

In China, including Macau and Hong Kong, the executive branch is also dominant. Macau is strictly subject to US coercion for its being the only place in China with gambling businesses - a sector with high risks of money laundering in the US dollar system - and 'voluntarily' surrenders its executive, legislative and arguably judicial power with regard to financial sanc-

Governance: How the US Unilateral Sanctions against Iran Changed the Rules of Financial Capitalism', American Journal of Sociology (forthcoming).

15 See BNP Paribas, who arguably paid for their 'trust' in the judicial branch instead of the executive branch of the US authorities: United States $v$ BNP Paribas SA, US District Court, Southern District of New York, No. 14-cr-00460 (LGS) (SDNY April 30, 2015). Also, DOJ (US Dept. of Justice): United States District Court, Southern District of New York, United States of America v BNP Paribas, SA, Defendant. <www.justice.gov/sites/default/files/opa/legacy/2014/06/30/statement-of-facts.pdf $>$.

${ }_{16}$ 'To waive (1) any claim by or on behalf of Respondent [Standard Chartered Bank], whether asserted or unasserted, against OFAC, the U.S. Department of the Treasury, and/or its officials and employees arising out of the facts giving rise to the enforcement matter that resulted in this Agreement, including but not limited to OFAC's investigation of the Apparent Violations, and (ii) any possible legal objection to this Agreement at any future date'. IV. Terms of Settlement, P 13, para 64.B, Settlement Agreement between the U.S. Department of the Treasury's Office of Foreign Assets Control and Standard Chartered Bank, 9 April 2019: <www.treasury.gov/resource-center/sanctions/CivPen/Documents/scb_settlement .pdf; www.treasury.gov/resource-center/sanctions/OFAC-Enforcement/Pages/20190409.aspx.>.

17 ibid P 13, para 63.

18 For details see Mallard and Sun (n 14).

19 Narcotics Trafficker Kingpin OFAC Removals: <www.ofacremoval.com/narcotics-sdn-removal>; US Treasury, OFAC enforcement, Kingpin Act Designations; Counter Narcotics Designations Removals and Designation Update; Cuba Designation Removal, 19 December 2019 'The following deletions have been made to OFAC's SDN List' <www.treasury.gov/resource-center/sanctions/OFAC-Enforcement/ Pages/20191219_33.aspx.>.

20 US Treasury, Treasury Removes Sanctions Imposed on Turkish Ministries and Senior Officials Following Pause of Turkish Operations in Northeast Syria - OFAC lifts sanctions on two ministries and three ministers (23 October 2019) <https://home.treasury.gov/news/press-releases/sm801>. 
tions, by which it is merely a mirror of UNSC plus US/EU sanctions. ${ }^{21}$ The aim is to avoid being blacklisted by the US authorities, a lesson they learned from the crippling US sanctions on Banco Delta Asia from 2005 to the present (and very likely forever), for this local bank's alleged involvement in North Korean money laundering. ${ }^{22}$ Any de-listing appeal in Macau shall thus be dealt with by the relevant bank directly with the US Treasury or in the US federal courts. ${ }^{23}$ In practice the Macau government and court have simply dismissed any de-listing complaints, often without stating any specific reasons. ${ }^{24}$ There is no administrative de-listing procedure available in any administrative agency, either. ${ }^{25}$

Hong Kong pursues the same objective: it relinquishes much of its de facto power in exchange for the support of the US federal government agencies, whose influence dominates Financial Action Task Force on Money Laundering (FATF) mutual evaluations and the presence of American banks and the Asian offshore US dollar market there as well as its dollar-backed currency system. ${ }^{26}$ On the level of the Anti-Money Laundering/Combating the Financing of Terrorism/Countering the Financing of Proliferation (AML/CFT/CFP) administrative regulation, ${ }^{27}$ the Hong Kong regulatory authority for banking officially acknowledges

21 Macao Monetary Authority: Anti-Money Laundering (AML) and Combating the Financing of Terrorism (CFT) Notice and Guideline for Financial Institutions (Update January 2019) <www.gif.gov .mo/web1/doc/AMCM/Banking/English/1.aml_cft_gudileine_eng_2019_final.pdf.>. Part 7: Financial Sanctions, Article 7.2.2. (P 17): 'institutions may choose to have access to such database provided by some well-known service providers [from the US, UK or Canada] for performing the screening' (emphasis added). Article 7.2.3: 'database for screening is up-to-date and covers at least those persons and entities subject to local, UNSC or other [US and EU] international sanctions'.

${ }_{22}$ FinCEN, Finding that Banco Delta Asia SARL is a Financial Institution of Primary Money Laundering Concern - 31 CFR Part 103 (20 September 2005) <www.fincen.gov/resources/statutes -regulations/federal-register-notices/finding-banco-delta-asia-sarl-financial $>$ accessed 28 May 2020; 31 CFR $§ 1010.655$ - Special measures against Banco Delta Asia $<$ www.law.cornell.edu/cfr/text/31/1010 $.655>$ accessed 28 May 2020.

${ }_{23}$ Banco Delta Asia, SARL et al v FinCEN et al (US District Court for the District of Columbia, filed 14 March 2013); 'US authorities and Banco Delta Asia agree in extra audit to solve years long sanction dispute' (Macau News Agency, 10 October 2018) <www.macaubusiness.com/macau-us-authorities-and -banco-delta-asia-agree-in-extra-audit-to-solve-years-long-sanction-dispute-media/>; 'US authorities rejected Delta Asia Financial Group motion to remove sanctions imposed 12 years ago' (Macau News Agency, 11 October 2019) <www.macaubusiness.com/us-authorities-rejected-delta-asia-financial-group -motion-to-remove-sanctions-imposed-12-years-ago/>.

24 An example is Banco Delta Asia: 'according to Chapter II of Part IV of the FSAM (Financial System Act of Macau), "among the additional sanctions that may be applied for contraventions is publication of the sanctions. In this case, the contraventions and any sanctions applied will be published in two local newspapers, one being Chinese and the other one Portuguese" ... we asked several Macau law firms if they knew about this ad [of publication of the sanctions] and, by the way, if they could send it to us. It was certainly bad luck and coincidence, but nobody knew about it ... Two weeks ago, the Court of Final Appeal dismissed another appeal filed by Delta Asia Bank, in which it challenged that decision of the former Chief Executive'. '12 Years of Silence' (Macau News Agency, 7 April 2020) <www .macaubusiness.com/12-years-of-silence/> accessed 28 May 2020.

${ }_{25}$ Financial Intelligence Office, Macau SAR: The Anti-Money Laundering and Counter-Terrorist Financing Legislation and Regulations <www.gif.gov.mo/web1/en_law.html> accessed 28 May 2020.

26 Article 111, Hong Kong Basic Law.

27 Hong Kong Monetary Authority (HKMA), Guidelines on Anti-Money Laundering and Counter-Financing of Terrorism (Updated October 2018) <www.hkma.gov.hk/media/eng/doc/key -information/guidelines-and-circular/guideline/g33.pdf.>. 6.11 Sanctions imposed by other jurisdictions; 6.13: 'a database maintained by a third party service provider'; 6.14: 'any updates to UNSCRs or 
the mandatory implementation of US and EU unilateral and extraterritorial sanctions by the local branches or offices of global banks there. The slight differences with Macau are twofold. First, Hong Kong, as an international financial and trade centre with a good understanding of the common errors in Romanizing names and aliases in many Asian languages, renders an administrative petition mechanism ${ }^{28}$ (similar to, but much more friendly than, the OFAC removal petition) by which the applicant may ask the administrative agency to clarify the accurate 'aka' information and state reasons so as to avoid any factual error, besides the judicial remedies embedded in the common law system. Second, the administrative law enforcement agencies including the Police Force and Customs, under external pressure from US diplomacy and the UNSC sanctions expert reports, had been actively investigating about 1800 suspected money laundering cases ${ }^{29}$ and 180 sanctions violation cases every year ${ }^{30}$ through front or shell companies or shipping companies in Hong Kong especially related to Iran and North Korea. This is the socio-legal background of the administrative remedies for financial sanctions in Hong Kong, which will be further developed in Section 5 below.

Over the two special administrative regions, the Chinese central government has the exclusive rights to decide the application to the regions of any international agreements and 'to make appropriate arrangements for the application', ${ }^{31}$ which could be somehow 'circumvented ${ }^{32}$ by

[foreign unilateral] sanctions lists'; 6.15: 'should include in its database: (iii) any relevant designations by overseas authorities which may affect its operations' (emphases added).

28 For details, see Section 5 of this chapter.

29 Figure 3.2: Number of ML investigations in 2013-2017, Hong Kong Money Laundering and Terrorist Financing Risk Assessment Report, April 2018, 15: <www.fstb.gov.hk/fsb/aml/en/doc/hk-risk -assessment-report_e.pdf $>$.

${ }_{30}$ 'Huge increase in investigations by Hong Kong authorities into suspected breaches of UN sanctions in last five years: Police and customs investigated 14 cases between them in 2014 - and 182 last year; Undersecretary for Commerce Bernard Chan says no cases resulted in charges as government deregistered suspect companies or denied suspicious ships entry' (South China Morning Post, 23 January 2019) <www.scmp.com/news/hong-kong/politics/article/2183311/huge-increase-investigations-hong -kong-authorities-suspected $>$.

31 Article 153, The Basic Law of the Hong Kong Special Administrative Region of the People's Republic of China ('the Basic Law' hereafter).

32 Strictly speaking, it might not constitute to a serious circumvention, as the following MOUs and seminars are closely associated with Section 1 of Chapter V Economy, particularly Article 109, of the Basic Law: Hong Kong government 'shall provide an appropriate economic and legal environment for the maintenance of the status of Hong Kong as an international financial centre'. 
the US-Macau MOU ${ }^{33}$ or the US-Hong Kong MOU ${ }^{34}$ or joint US training seminars, ${ }^{35}$ as long as Beijing does not implicitly object to the detailed arrangement of such MOUs or seminars.

In Mainland China's sanctions law, except for the temporary unilateral trade sanctions (counter-)measures, often declared by the Ministry of Commerce, and the Export Control Law passed very recently on 17 October 2020, it is mainly a set of internal administrative regulations by which the People's Bank of China ( $\mathrm{PBC}$ ), working as the AML/CFT/CFP ${ }^{36}$ law enforcement agency in China, forward to Chinese banks the administrative notifications from the Ministry of Foreign Affairs implementing specific UNSCR(s). ${ }^{37}$

It is, however, another story with regard to legal practices in China. For instance, the UNSCR has never sanctioned the Central Bank of Iran (CBI) or Iran in general, and the same applies to most regular business settlements with Russia, Syria and Venezuela. For this reason, Chinese banks shall not, or at least are not required to, enforce any sanctions on these entities not designated by the UNSCRs. The legal practices show a distinct picture of transnational legal orders in three respects. ${ }^{38}$

33 US Dept of State, U.S.-Macau Policy Act Report, As of April 1, $2003<$ https://2001-2009.state .gov/p/eap/rls/rpt/19555.htm>. 'Macau's financial regulatory authorities continue to direct financial institutions ... using lists of individuals and entities designated by the US under relevant authorities, as well as the UN 1267 Sanctions Committee ... The Macau government has responded quickly and cooperatively when asked by US law enforcement agencies for assistance on anti-terrorism matters. Macau participated in a voluntary self-assessment exercise for non-Financial Action Task Force (FATF) members [Note: when Mainland China was not an FATF member at that time] in which it evaluated its compliance with the FATF's Eight Special Recommendations on Terrorist Financing ... Under the terms of a September 2000 bilateral Memorandum of Understanding, our two [U.S. and Macau] governments cooperate in enforcing ...' (emphases added).

${ }_{34}$ The US-HK FIU (Financial Intelligence Unit) MOU in the framework of the Egmont Group (of which Mainland China is not a member) as well as the US-HK securities regulation MOU signed in 1995 and renewed in 2017.

${ }_{35}$ 'The C\&ED [Customs and Excise Department of Hong Kong SAR] and the US Immigration and Customs Enforcement Homeland Security Investigations also co-hosted a seminar on TBML [trade-based money laundering] in January 2017 to share TBML enforcement experience, typologies and case studies with the banking industry. Over $100 \mathrm{AML} / \mathrm{CFT}$ and financial crime compliance staff from more than 30 banks participated'. Hong Kong Money Laundering and Terrorist Financing Risk Assessment Report, April 2018, para 5.2.23, P 47 <www.fstb.gov.hk/fsb/aml/en/doc/hk-risk-assessment-report_e.pdf >. See also HKMA AML/CFT Training \& Seminars < www.hkma.gov.hk/eng/key-functions/banking/anti -money-laundering-and-counter-financing-of-terrorism/training-and-seminars/> accessed 28 May 2020.

36 PBC never officially acknowledges it has exclusive ‘jurisdiction' over CFP. The State Commission Office of Public Sectors Reform (SCOPSR) clarifies the specific power of each agency. AML/CFT was a 'jurisdiction' of the Ministry of Public Security (MPS) only prior to the AML Law of China in 2006. Since 2006, the MPS reserves AML/CFT powers in the Penal Code, and the PBC deals with the administrative, not criminal, violations defined by the AML Law. On CFP, the SCOPSR never issued any public notification: it is presumed to be an exclusive power of the Ministry of Foreign Affairs (MFA). As the MFA does not have supervisory power over banks, the implementation of the UNSCRs has to conduct a form of Notification-Forward (MFA to PBC - PBC to banks) for now.

37 The author's interviews with senior AML officers or compliance managers in Chinese banks or foreign banks in China. Also, the Chinese official position is that China does not acknowledge any unilateral and extraterritorial sanctions outside the UNSC resolutions. See also the chapter by Congyan Cai in this book.

38 For the latter two legal orders, see Mallard and Sun (n 14). 
First, although no bank in China is allowed to share its customer information with any foreign court ${ }^{39}$ as per requirements of the Chinese Banking Law ${ }^{40}$ and AML Law, ${ }^{41}$ or even arguably, its Penal Code, ${ }^{42}$ it is not considered a violation of any legal obligations ${ }^{43}$ if any banks there, particularly Chinese branches of global banks, internally decide to use any sanctions screening software, designation lists or AML/CFT/CFP protocols sourced from foreign countries or foreign suppliers.

Second, as China has been the largest contributor to international trade, Chinese national banks have been widely expanding their international network through new offices and branches across the world, by which its branches in New York and in the EU, are subject to the governance of foreign sanctions laws. The leading Chinese banks such as the Agriculture Bank of China ${ }^{44}$ (which runs China's largest banking network), like other global banks from the EU, have been 'educated' by the US law enforcement agencies through the AML fines and settlement, resulting in 'voluntary' pledges from the big Chinese banks to abide by sanctions standards of the US as well as the EU for the sake of maintaining direct access to the money supply of global central banks as well as to the international settlement network in the dollar/ euro system. This has led the three largest Chinese retail banks, all with branches in the US/ EU, to become the first to enforce restrictive measures on Iranian clients, as complained of by the Iranian Ambassador in Beijing. ${ }^{45}$

Third, for those local Chinese banks with no international network, global banks, mainly those from the EU, become their leading partners serving as their correspondent banks in charge of international payments in much the same way as Deutsche Bank serves as a correspondent agency for Swedbank, ${ }^{46}$ by which all these Chinese banks in this type of correspond-

39 See, for instance, 'US Appeals Court Upholds Ruling Against Chinese Banks in North Korea Sanctions Probe' (Reuters, 31 July 2019) <www.reuters.com/article/us-usa-trade-china-banks/us-appeals -court-upholds-ruling-against-chinese-banks-in-north-korea-sanctions-probe-idUSKCN1UQ03U>; 'Three Chinese Banks Hit by US Probe into North Korea Links' (Financial Times, 25 June 2019) <www .ft.com/content/2a74e0d6-972c-11e9-8cfb-30c211dcd229>.

40 Article 29, Chapter 3: Protection on Depositor [Clients], Commercial Banking Law of China.

41 Article 5, Article 32, AML Law of China.

42 Depending on the interpretation of 'state secret', in Article 111 of Penal Code, Article 9 of Protecting State Secret Law and Article 30(2) AML Law of China.

43 Although an application of foreign-sourced software, screening database and protocol is not a violation or conflict of domestic law, it is a very sensitive area for chief compliance officers in Chinese banks or foreign banks in China, as documented in interviews, considering the Chinese position (in a Soviet doctrine of absolute sovereignty) against any form of unilateral and extraterritorial sanctions, particularly the 'long arm governance of the US [sanctions] law'. For more details, search 'long arm governance' in Chinese at People's Daily <http://data.people.com.cn/rmrb $>$. See also the chapter by Congyan Cai in this book.

${ }_{44}$ DFS (Department of Financial Services of the State of New York) and ABC (Agricultural Bank of China) Consent Order Under New York Banking Law $\S \S 39$ and $44<$ www.dfs.ny.gov/docs/about/ ea/ea161104.pdf>; DFS Fines Agricultural Bank of China \$215 Million for Violating Anti-Money Laundering Laws and Masking Potentially Suspicious Financial Transactions <www.dfs.ny.gov/about/ press/pr1611041.htm> accessed 28 May 2020.

45 These measures were reported by Iranian news agencies like IRNA, Mehr, and the Financial Tribune, which lead the Iranian Ambassador in Beijing to negotiate with the Chinese Ministry of Foreign Affairs and communicate with the Chinese Banking Regulatory Commission and three retail banks $<$ www.mofcom.gov.cn/article/i/jyjl/j/201710/20171002662576.shtml>.

46 'Deutsche Bank, Wells Fargo Were Swedbank's Dollar Correspondents'(Bloomberg, 20 February) $<$ www.bloomberg.com/news/articles/2019-02-20/deutsche-bank-wells-fargo-were-swedbank-s-dollar 
ent bank agreement have to implement the same set of sanctions screening rules and protocols as their EU partners, who in practice have relocated their global sanctions offices to New York and thus adopt a set of designations inclusive with the US, EU and UNSC sanctions, including extraterritorial sanctions on Iran, Russia, Syria and Venezuela. These local Chinese banks, as I documented in fieldwork interviews, have to follow the rules and protocols of their correspondent bank, not only because global correspondent banks are increasingly subject to US secondary sanctions, as shown in the Swedbank case, ${ }^{47}$ but also since some of them have seen restrictions placed on certain functions of their offshore general accounts in Hong Kong for not doing so, resulting in returns or refusals of international money transfers. ${ }^{48}$

\section{SOURCES AND TYPES OF UNILATERAL AND EXTRATERRITORIAL SANCTIONS-RELATED DISPUTES IN MAINLAND CHINA}

This section will present the three main disputes in China arising out of foreign sactions, namely:

I. Restrictions on opening bank accounts or on money transfer services in China.

II. Letter of credit disputes due to US/EU unilateral and extraterritorial sanctions on central banks (in Iran, Syria and Venezuela) or major commercial banks (in Russia).

III. Letter of credit disputes due to US/EU sanctions on certain countries in general.

The first type of dispute over individual bank accounts could be explained by the reliance of Chinese banks on foreign-sourced sanctions screening technologies, the international settlement network, and global correspondent banks in the US dollar/euro system.

The latter two types of disputes are between Chinese and foreign business entities in international trade settlement because of the high reliance of Chinese goods exporters on the settlement services of global banks particularly in those countries outside East Asia, often beyond the branch network of Chinese banks. Such reliance on banks is inevitable because the best risk mitigation in collecting money from high-risk countries like Iran, ${ }^{49}$ as they shared with the author in interviews, is trade settlement by letter of credit issued by accredited global banks. This, however, leads to a bank payment problem, because global banks, targeted by the US unilateral secondary sanctions with multi-billion-dollar fines like those on HSBC,

-correspondents>; 'Swedbank Report Spotted Anti-Money-Laundering Breaches' (Reuters, 27 March 2019) <www.reuters.com/article/us-europe-moneylaundering-swedbank/swedbank-report-spotted-anti -money-laundering-breaches-swedish-tv-idUSKCN1R721L>.

47 'Swedbank Notifies OFAC of Potential Sanction Violations' (11 March 2020) <https://swedbank .com/newsroom/press-releases.details.56AF917DE45D1401.html>.

48 It is not based on open records of any administrative investigation but a summary of the interviews with experienced bank AML/CFT officers or Chief Compliance Officers in Asia.

49 'An IMB [the International Maritime Bureau (IMB), a unit of Commercial Crime Services of the International Chamber of Commerce (ICC)] investigation on behalf of local banks indicates that roughly two thirds of such transactions on the secondary forfaiting market were fraudulent'. ICC: Trade Fraud hits Iranian shipments <www.icc-ccs.org/index.php/406-trade-fraud-hits-iranian-shipments> accessed 28 May 2020. 
Standard Chartered and BNP Paribas, took a zero-risk approach towards Iranian payments, ${ }^{50}$ relocated their global sanctions compliance offices to New York and 'voluntarily' subjected themselves to the US unilateral sanctions regulations. For this reason, Chinese banks have become increasingly exposed to the enforcement of US unilateral sanctions laws and regulations. ${ }^{51}$ When a global bank indirectly disrupted the money transfer in a correspondent bank in the third legal order, or when a Chinese bank - often its overseas branch hidden in some process of international payment settlement - directly did so in the first or second order, there would be a payment settlement dispute in international trade between business entities or with their letter of credit payer/payee bank.

To make matters worse, international trade settlement practices in Iran, ${ }^{52}$ Syria $^{53}$ and Venezuela $^{54}$ all rely heavily on the cross-border clearing service of their central banks. This is often due to the Foreign Reserves (FX) control measures implemented by the central bank $^{55}$ and through the central bank's front or shell companies in a third-party country. Due to US pressure on their central banks' shell company accounts in a third-party country like the United Arab Emirates, ${ }^{56}$ bilateral payment is disrupted occasionally, leading to Type II sanctions-related disputes in China.

To put it another way, international trading firms from countries under US/EU unilateral sanctions do not have many choices when it comes to making international payments and are limited to global, Chinese or Russian banks. Above all, their domestic banks or their shell company accounts in a third-party country like the United Arab Emirates are blacklisted by global banks, ${ }^{57}$ as the list of countries under unilateral sanctions heavily overlaps with that of high-risk countries blacklisted by the $\mathrm{FATF}^{58}$ or the lists of leading sanctions screening

50 Grégoire Mallard, Farzan Sabet and Jin Sun, 'The Humanitarian Gap in the Global Sanctions Regime: Assessing Causes, Effects and Solutions' (2020) 26(1) Global Governance: A Review of Multilateralism and International Organizations.

51 (n 39).

52 'Banana Containers Held Up at Customs' (Financial Tribune, 9 May 2020) 'piled up at Iran's southern ports but the Central Bank of Iran failed to allocate foreign currency needed to start their customs clearance' $<$ https://financialtribune.com/articles/domestic-economy/103267/banana-containers -held-up-at-customs $>$.

53 Al-Jaafari [Syria's UN Ambassador]: Unilateral Coercive Economic Measures Hamper Syria's Response to Covid-19 (11 May 2020): 'the Syrian Central Bank had not been able to take advantage of frozen Syrian funds abroad for years with the aim of financing the import of materials related to the basic needs of the Syrian people'< <ttps://english.almanar.com.lb/1028920>.

54 See for example Fulvio Italiani, 'Foreign currency regulations and price controls in Venezuela' (April 2017) <www.legalmondo.com/2017/04/foreign-currency-regulations-venezuela/>; Emiliana Disilvestro and David Howden, 'Venezuela's Bizarre System of Exchange Rates' (7 January 2016) $<$ https://mises.org/library/venezuelas-bizarre-system-exchange-rates $>$.

${ }_{55}$ Vice-Governor of the Central Bank of Iran (CBI) responsible for foreign exchange $<$ www .centralbanking.com/central-banks/reserves/foreign-exchange/3668511/central-bank-deputy-arrested-as -iran-grapples-with-forex-crisis>.

56 EO 13382 and EO 13846 (by which NIOC and its shells in UAE are targeted) <https:// sanctionsnews.bakermckenzie.com/ofac-designates-five-uae-businesses-involved-in-iran-related -transactions/> accessed 28 May 2020.

57 ibid.

58 FATF High-risk and other monitored jurisdictions <www.fatf-gafi.org/countries/\#high-risk> accessed 28 May 2020; https://www.fatf-gafi.org/publications/high-risk-and-other-monitored -jurisdictions/documents/call-for-action-february-2020.html>. 
software suppliers identifying the beneficiary owner of each business entity particularly those shell companies in third-party countries.

Alternative channels of international bank settlement have soon withered as well. One is the Chinese banks, like Kunlun Bank, whose controlling shareholder was directly forced by the US Secretary of State to suspend its settlement business with Iran. ${ }^{59}$ Also, for the chilling effects of US law enforcement on the Agriculture Bank of China, all major Chinese banks have decided to take restrictive measures towards Iranian accounts often by setting a daily cap on money transfers under which the counterpart exporters would not often receive a timely payment in due amount. A concrete example is that, in the Covid-19 pandemic, the Iranians have found the most, if not the only, reliable bank account to quickly accept donations and to procure medical supplies from the Chinese private sector is through the general account of their Embassy in China, held in the head office of the Bank of China in Beijing. ${ }^{60}$

The other alternative channel is the international payment network through Russian banks, intensively used by Syria ${ }^{61}$ and Venezuela. ${ }^{62}$ This is confirmed by the interview with a Chinese exporter with first-hand insights into humanitarian medical exports to the Middle East, especially Iran and Syria, which are supposed to be exempted from any UN or unilateral sanctions ${ }^{63}$ as requested by the UNSCRs. ${ }^{64}$ 'This channel has been quickly drying up as well, as it has now become a top factor for small and medium-sized traders from Mainland China improperly using offshore accounts in Hong Kong, resulting in non-compliant or even illegal high-risk red-flag labelling for which their bank accounts are forcefully closed by bank compliance. ${ }^{65}$ A trader 'receiving money transfer from a Russian [US-] sanctioned bank without reporting in advance, with a couple of other income streams from high-risk countries with no pre-reporting, was treated with all accounts being closed in spite of there being no transaction in violation

59 'China National Petroleum Corp May Cut Kunlun Bank's Ties to Iran: Sources' (Reuters, 21 December 2018) <www.reuters.com/article/us-china-iran-banking-kunlun/china-national-petroleum -corp-may-cut-kunlun-banks-ties-to-iran-sources-idUSKCN1OK1EA>; 'Exclusive: As US Sanctions Loom, China's Bank of Kunlun to Stop Receiving Iran Payments - Sources' (Reuters, 23 October 2018) $<$ https://uk.reuters.com/article/uk-china-iran-banking-kunlun-exclusive/exclusive-as-u-s-sanctions -loom-chinas-bank-of-kunlun-to-stop-receiving-iran-payments-sources-idUKKCN1MX1L5>.

60 As reflected by the announcements of the Iranian Embassy in Beijing on Weibo in 2020 over the pandemic, and re-affirmed with an experienced expert with contacts there.

${ }_{61}$ 'Exclusive: Russian Banks Strengthen Ties With Blacklisted Syrian Lenders' (Reuters, 31 October 2013) <www.reuters.com/article/us-syria-crisis-russia-banks/exclusive-russian-banks-strengthen-ties -with-blacklisted-syrian-lenders-idUSBRE99U0Q620131031>; 'Report: WikiLeaks Withheld Email Linking Syria to Russian Bank' (Washington Examiner, 9 September 2016) <www.washingtonexaminer .com/report-wikileaks-withheld-email-linking-syria-to-russian-bank>.

62 'Exclusive: Venezuela Shifts Oil Ventures' Accounts to Russian Bank - Document, Sources' (Reuters, 9 February 2019) <www.reuters.com/article/us-venezuela-politics-pdvsa-banks -exclus/exclusive-venezuela-shifts-oil-ventures-accounts-to-russian-bank-document-sources -idUSKCN1PY0N3>.

63 See for example EU Council Decision (CFSP) 2017/2074, Article 4.1, 4.2 and 6.6 on Venezuela, and OFAC (Office of Foreign Asset Control, US Treasury) Guidance Related to the Provision of Humanitarian Assistance and Support to the Venezuelan People, 6 August 2019 <www.treasury.gov/ resource-center/sanctions/Programs/Documents/20190805_vz_humanitarian_guidance.pdf>.

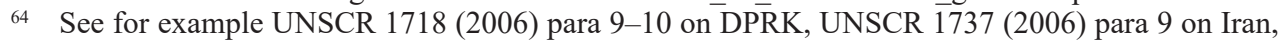
UNSCR 2254 (2015) para 12, UNSCR 2268 (2016) para 5, and UNSCR 2235 (2016) on Syria.

${ }_{65}$ The author's interview with experienced specialists from manufacturers and exporters in East Asia in Spring 2020. 
of any UN or unilateral sanctions at all' ${ }^{66}$ Despite there being no UN sanctions on Russia, the legal practice is that 'your company account can receive only business-to-business (not individual) money transfers from non-sanctioned banks in Russia conditioned on reporting in advance. With six US-sanctioned banks, you cannot conduct any transactions; otherwise, the receipts shall be returned and your accounts in trouble'. ${ }^{67}$ This case is also very helpful in understanding why this chapter is constructed around the legal practices in China including Hong Kong, as it is the largest offshore bank settlement centre for the Chinese private imports and exports sector as well as their counterparty traders around the world. The picture of unilateral and extraterritorial financial sanctions would not be complete without examining the transnational legal orders in both civil law and common law systems through onshore and offshore banking services.

\section{REMEDIES AND PROCEDURES IN MAINLAND CHINA}

As already underlined, the UNSC resolutions have never sanctioned the Central Bank of Iran, Iranians or Iran in general, and the same is true of Russia, Syria and Venezuela. But global banks, particularly their branches as well as their local partners in correspondent bank relationships in Mainland China and Hong Kong, have to enforce US and EU sanctions for fear of US secondary sanctions. This leads to conflict or tension between positive law on paper and legal practices in international bank settlement in China. It is also where individuals or banks from unilateral and extraterritorial sanctioned countries would look for diplomatic protection from their ambassador in Beijing, as well as professional advice from their trusted lawyers or senior bankers in China. One example is the practical difficulty of opening bank accounts for citizens from US/EU sanctioned countries. Another example is where the cross-border bank settlement system does not work, as explained in Section 3, leading the above presented two types of sanctions-related letters of credit disputes between the relevant parties, like the letter of credit payee, payer, or their banks. ${ }^{68}$

Moreover, although money payments to Iran, Syria or Venezuela in themselves are not considered to violate inexistent Chinese sanctions, they are very likely to be in violation of the AML/CFT/CFP laws for failing to satisfy either the enhanced regulatory requirement of the risk-based approach with regard to politically exposed person (PEP) screening, ${ }^{69}$ or the beneficial ownership review on the counterparty bank or payers/payees from high-risk jurisdictions, for instance, as blacklisted by the FATF. Reported cases have shown that some banks have been punished by the $\mathrm{PBC}$ for such reasons. There is a trend towards higher administrative fines by the $\mathrm{PBC}$ on Chinese banks and also foreign banks in China for violations of AML/ $\mathrm{CFT} / \mathrm{CFP},{ }^{70}$ particularly in the context of the fourth FATF mutual evaluations on China and

6 ibid.

67 ibid.

68 For details, see Section 4.3 of this chapter.

69 'FATF Recommendation 12 defines a PEP as being someone who has been (but may no longer be) entrusted with a prominent public function'. For details, see 'LexisNexis, 10 Things You Need to Know about PEP Screening' <www.lexisnexis.com/risk/intl/en/resources/infographics-factsheets/pep-quick -reference-sheet.pdf $>$.

70 See for example PBC Shanghai AML/CFP fines on BNP Paribas (China) Limited, its governor, $\mathrm{COO}$, and Compliance Chief, respectively for CNY 2.7 million, 60 thousand, 60 thousand and 45 thousand yuan as of 26 May 2020: PBC Shanghai Fine (2020) \#9, \#3, \#10, and \#11. 
the implementation of China's big data governance project. The relevant banks, particularly foreign banks in China in this case, are often unsure about what remedies they could look for from the AML law enforcement agency and/or other authorities in China, what procedures they should follow or pay attention to, and whether or not it is wise to challenge the PBC in the Chinese courts, for which they look for legal advice from practice lawyers with cutting-edge insights in this particular field. These questions are extremely relevant because of the marked differences between the Chinese law of administrative procedure along with its socio-legal course on AML/CFT/CFP law enforcement and that in the US and EU.

\subsection{Administrative Complaint and Reconsideration}

So, when an Iranian ${ }^{71}$ student, for example, finds it difficult to open a bank account, as the author documented from the branch AML specialist of a major national bank in China, the best legal advice is to make a complaint ${ }^{72}$ first to the bank's head office, and, if that fails, to the Department of Written Complaints of the General Office - the Chinese Bank Regulatory Commission (CBRC) - which has direct and immediate supervisory power over any bank. That is why the Iranian ambassador in Beijing did so at first. ${ }^{73}$

To be more specific, it should be highlighted that the legal sources of administrative remedies for individuals and banking institutions are different with regard to restrictions on opening bank accounts or money transfer services in China. Besides the administrative complaints, foreign banks from high-risk countries with account restrictions in China or a Chinese bank with AML fines for transactions with them could also seek relief from administrative reconsideration at the $\mathrm{CBRC}$ and the $\mathrm{PBC}$, respectively, over banking supervision ${ }^{74}$ and $\mathrm{AML} / \mathrm{CFT}^{75}$ matters.

71 The Iranian community in China has a sizable population of students, businessmen and visitors. Each year about 70,000 people visit China from Iran. But it is a very minor group of Syrians and Venezuelans for an estimate of about 100 long-term residents each in China.

${ }_{72}$ The general legal term for this special procedure is administrative petition, but the specific term used by the $\mathrm{CBRC}$ is complaint. For a general comparison between administrative petition and litigation, see: Taisu Zhang, 'Why the Chinese Public Prefer Administrative Petitioning over Litigation [J]' (2009) 3 Sociological Studies.

73 (n 45).

74 Article 5, Administrative Reconsideration Measures of China Banking Regulatory Commission of 2004 (ARM-CBRC). '(1) Refusing to accept the warning, fine, confiscation of illegal income, order to suspend business, revocation of financial license and other decisions made by the CBRC or its dispatched office; (2) Refusing to accept the decision made by the CBRC or its dispatched office to cancel the qualifications of directors and senior managers of banking financial institutions for a certain period of time or for life' (emphases added).

75 Article 7, Administrative Reconsideration Measures of the People's Bank of China of 2001. '(1) Refusing to accept the administrative penalty decisions made by the People's Bank of China, such as warning, fine, confiscation of illegal income, confiscation of illegal property, suspension or cessation of financial business, order to suspend business for rectification, revocation of business license for financial business, revocation of representative offices of financial institutions, etc.; (2) Refusing to accept the decision made by the People's Bank of China to disqualify senior managers of financial institutions' (emphases added). 
Administrative reconsideration ${ }^{76}$ is a very important legal remedy because in China's fragmented administrative procedural laws and regulations there are at least seven situations in which the administrative court would not admit a case unless submitted for administrative reconsideration first: namely, natural resources, tax, patent, customs, price, parade or march, and financial regulation but excluding $\mathrm{AML} / \mathrm{CFT} .{ }^{77}$ Administrative reconsideration works like a tribunal ${ }^{78}$ composed of professional government legal officers (alongside industry experts and lawyers occasionally) of the administrative agency or the central or provincial government. The government legal officers in administrative reconsideration are required to pass the national judicial examination like any professional lawyer in China. Bear in mind that (a) unlike in the EU there is no subsidiarity doctrine in China, and (b) unlike the US Federal system, China has a unitary political system. The general logic of this institutional design is to run a review system within the executive branch, by which a higher tier of government or its specific administrative agency shall review the specific act of a lower tier or its agency with regard to its specific administrative decision, enforcement or fine on civil entities.

The form is similar in Hong Kong's tax dispute with the Inland Revenue Department, which would refer any dispute first to a tax tribunal. In the UK, there are also many similar tribunals created by statute to deal with particular types of regulatory, disciplinary or administrative matter. ${ }^{79}$ But the substance in China is very different in a legal order dominated by the

76 He Xin, 'Administrative Reconsideration's Erosion of Administrative Litigation in China' (2014) 2(2) The Chinese Journal of Comparative Law 252-69.

77 '(9) Legal liability for acts violating relevant anti-money laundering regulations: Article 191 of China's Criminal Law provides penalties for five acts that facilitate money laundering by units and individuals including financial institutions. However, the People's Bank of China shall punish money laundering that is obviously minor and does not constitute a crime in accordance with the provisions of this article ... the party subject to administrative punishment may choose to apply for administrative reconsideration, and the administrative organ at the next higher level or the administrative organ prescribed by laws and regulations may decide whether to correct or maintain the administrative punishment decision made by the administrative organ. The parties may also bring a lawsuit directly to the court, and the people's court shall decide whether to maintain or revoke the administrative penalty decision or change the judgment. If the party concerned chooses the administrative reconsideration procedure, he may also bring an administrative lawsuit to the people's court if he is not satisfied with the administrative reconsideration'. National People's Congress Standing Committee: Interpretation of the Law of the People's Bank of China, Chapter VII Legal Liability, 86-118 (February 2004).

78 There are three tiers of legal orders: (1) administrative reconsideration (AR) against a specific decision, enforcement or fine will be reviewed by a permanent AR commission composed of legal officers from its Department of Legal Affairs (not law enforcement or investigation) in a regional office, (2) AR against the regional office will be reviewed by the AR commission composed of legal officers from the CBRC Department of Legal Affairs, and (3) AR against the CBRC could be filed at the State Council (reviewed by its Legal Office, which is now part of the Ministry of Justice), or at court by administrative litigation against the CBRC/regional office. For details, see (nn 73, 75 and 76).

79 Employment Tribunals, Employment Appeal Tribunal, Competition Appeal Tribunal, First-tier Tribunal (General Regulatory Chamber, Health, Education and Social Care Chamber, Immigration and Asylum Chamber, Property Chamber, Social Entitlement Chamber, Tax Chamber, and War Pensions and Armed Forces Compensation Chamber) and Upper Tribunal (Administrative Appeals Chamber, Immigration and Asylum Chamber, Lands Chamber, and Tax and Chancery Chamber). 
executive branch, not the legislative or judicial branches. In $2017^{80}$ and $2018,{ }^{81}$ respectively, the PBC settled 60 and 83 administrative reconsideration cases over their punitive measures against financial institutions in China. Over the same period, the CBRC settled 580 and 467 administrative reconsideration cases over their punitive measures against financial institutions in China. By the rankings of the annual volume of reconsideration cases against any ministry or ministry-level agency, the $\mathrm{CBRC}$ has been a top-five administrative agency in the Chinese central government for filings by civil entities under this procedure.

The implication is that administrative reconsideration is considered as a relatively common remedy for the industry against the fines of the administrative agencies in China. In other words, for those readers who are not familiar with Chinese legal culture, it should be borne in mind that compared with administrative litigation in tribunals (to be explored in the following section), administrative reconsideration, which is still within the executive branch of Chinese government, is more acceptable, or at least, less offensive for banks and regulators alike.

\subsection{Administrative Litigation}

This procedure operates through the specialized chamber or court of administrative law that are similar to French administrative courts, where in financial regulation related administrative penalty cases, the chamber or court can review appeals against unfavourable administrative reconsideration or against a specific administrative fine by the administrative law enforcement agency directly. ${ }^{82}$ This procedure of judicial administrative litigation in administrative procedural law would be particularly useful to specific banking institutions claiming to be unfairly or inappropriately treated by a particular administrative agency. ${ }^{83}$

Again it is another story entirely in legal practice. Lawyers and senior bank officers with experience of compliance and AML/CFT/CFP report the following. It might consider a remedy from judicial administrative litigation if and only if they are individual clients with an AML violation penalty from the PBC. For financial institutions in China, 'you are literally committing suicide if you dare to do so' ${ }^{84}$ The statistics support this rule of thumb: until now,

80 Ministry of Justice, 'Statistics on Administrative Reconsideration and Administrative Litigation Cases in 2017'<http://sfks.moj.gov.cn/organization/content/2019-01/11/560 228922.html > accessed 28 May 2020.

81 Ministry of Justice, 'Statistics on Administrative Reconsideration and Administrative Litigation Cases in 2018' <www.moj.gov.cn/organization/content/2019-05/09/560_234638.html> accessed 28 May 2020.

82 See Minxin Pei, 'Citizens v Mandarins: Administrative Litigation in China' (1997) China Quarterly 832; Kevin J O'Brien and Lianjiang Li, 'Suing the Local State: Administrative Litigation in Rural China' (2004) 51 The China Journal 75-96; Xin He, 'Judicial Innovation and Local Politics: Judicialization of Administrative Governance in East China' (2013) 69 The China Journal 20-42; Ji Li, 'Suing the Leviathan-An Empirical Analysis of the Changing Rate of Administrative Litigation in China' (2013) 10(4) Journal of Empirical Legal Studies 815-46; Wei Cui, 'Does Judicial Independence Matter: A Study of the Determinants of Administrative Litigation in an Authoritarian Regime' (2017) 38(3) University of Pennsylvania Journal of International Law 941-98; Haibo He, 'How Much Progress Can Legislation Bring: The 2014 Amendment of the Administrative Litigation Law of PRC' (2018) 13 University of Pennsylvania Asian Law Review 1.

83 (n 75).

${ }^{84}$ The author's interview with the branch AML/compliance head of a Chinese insurance company with administrative AML fine by the regional PBC office in Winter 2018-19. 
no financial institution in China including any local branch of global banks has ever sued the PBC for any dissent with its AML/CFT fines, often amounting to many millions of dollars. The logic is simple: it is widely believed that the PBC, if offended, would immediately start a new round of on-site AML/CFT inspections, which would result in more violation findings with more fines and serious punishments like suspending certain bankers. Over the period of temporary suspension for investigation, it is not allowed to pay any remuneration but the minimum wage to the bankers concerned. At the end of the investigation, it is within the PBC's discretionary power to 'disqualify senior managers of financial institutions' based on Article 7 (2) of the PBC Law. ${ }^{85}$ For the reasons above, it is strongly recommended that banking institutions refrain from seeking a remedy of judicial administrative litigation against any AML/CFT decision by the $\mathrm{PBC}$ in any Chinese tribunal, it being preferable to resolve disputes through administrative complaint or reconsideration procedures.

\subsection{Judicial Litigation: Judicial Mediation and Adjudication}

Under China's civil procedural law, ${ }^{86}$ the courts can engage in mediation as well as adjudication. For practical reasons, a court will first encourage the parties to undertake a mediation process; if any party declines, then the court will adjudicate.

In sanctions-related disputes concerning letters of credit or other forms of payment or trade finance (e.g. T/T payment, collections, forfaiting, factoring, collection of promissory notes) ${ }^{87}$ the effect of extraterritorial sanctions by the US/EU is visible in China because normal bank settlements were blocked or disrupted in specific cases, as shown by the record of court cases in China. There is therefore an alternative litigation strategy for such unilateral sanctions-related disputes in China, arising out of the visible effects that unilateral sanctions have in disrupting settlement in international trade.

Indeed in cases of letter of credit disputes ${ }^{88}$ it is reasonable to take the view that in law the dispute is not against an AML/CFT decision but of a commercial nature. For this reason, the court could treat it as a normal civil case, protect the trade transactions and instruct the bank to deal with money transfer or reparations for the settlement struck in some known or unknown process due to the extraterritorial sanctions. As the court consents to it being heard as a commercial dispute, it is not required to be submitted for administrative reconsideration first. In other words, the wisdom of this litigation/defence strategy is to resolve a sanctions dispute by ignoring sanctions, and thus, it is not necessary to review restrictive measures.

5 (n 76).

86 Article 9, Civil Procedural Law of China (CPLC).

87 More examples are available at Trade Finance Business, Dept. of Corporate Banking in Bank of China: www.bankofchina.com/cbservice/cb3/, and Global Trade Receivable Finance solutions in HSBC: www.gbm.hsbc.com/solutions/global-trade-receivables-finance.

88 See for example Bank Pasargad dispute with its L/C counterpart bank in China, Bank Eghtesad كناب : Novin's correspondent account in Chinese Kunlun Bank, and Bank of Industry and Mine (Persian .ند) vs Chinese Kunlun Bank. 


\section{REMEDIES AND PROCEDURES IN HONG KONG}

As illustrated by the example of Chinese medical exporters to the Middle East in Section 3, Hong Kong is an international financial and trade centre for its sophisticated cross-border arrangement with Chinese exporters and their buyers in Syria, Iran, Venezuela, Russia and elsewhere through offshore bank accounts there, which are often connected with onshore bank accounts in Mainland China under Chinese law. Meanwhile, it is mandatory for global banks in Hong Kong to enforce US/EU coercive unilateral and extraterritorial sanctions, which might disrupt or block certain payments between the onshore and offshore accounts because of conflicts of laws in transnational legal orders. For these particular reasons, it is very important to understand the remedies and procedures in Hong Kong for unilateral sanctions, which could be viewed as the laws and practices of Chinese offshore banking denominated in US dollars as well as in Chinese currency. ${ }^{89}$

Hong Kong implements UNSC sanctions through a set of AML/CFT regulations, ${ }^{90}$ the core of which is the United Nations Sanctions Ordinance (Chapter 537) (UNSO)..$^{11}$ In addition to the Hong Kong Police and Customs as the main AML/CFT/CFP enforcement agencies, four other administrative agencies ${ }^{92}$ are also responsible for sanctions implementation, namely, the Commerce and Economic Development Bureau (C\&ED), the Trade \& Industry Department (TID), the Hong Kong Monetary Authority (HKMA) and the Securities and Futures Commission (SFC), with regard to implementing UNSC sanctions, trade sanctions and financial sanctions including US/EU unilateral sanctions.

Readers might notice the potential tensions between the C\&ED and two financial sanctions law enforcement agencies - HKMA and SFC. While only those acts in violation of the

89 See for example HKMA Booklet: HONG KONG: The Global Offshore Renminbi Business Hub <www.hkma.gov.hk/media/eng/doc/key-functions/monetary-stability/rmb-business-in-hong-kong/ hkma-rmb-booklet_accessible.pdf >; Hong Kong Financial Services Development Council: Hong Kong: A Leading Financial Hub of Offshore RMB: 'RMB trade settlement handled by banks in Hong Kong ... accounting for $89 \%$ of total RMB cross-border trade settlement [in the world]' <www.fsdc.org.hk/ en/leaders_blog/2020/2>; SWIFT 'More than 100 countries are now using the RMB for payments with China and Hong Kong' (27 October 2016) <www.swift.com/insights/press-releases/more-than-100 -countries-are-now-using-the-rmb-for-payments-with-china-and-hong-kong; 'Investment from Hong Kong ... accounts for two thirds of China's overall foreign direct investment inflows, Hong Kong remains key gateway as China's FDI' (South China Morning Post, 17 October 2010) <www.scmp.com/ economy/china-economy/article/3033377/hong-kong-remains-key-gateway-chinas-fdi-rises-29-cent -first>.

90 Anti-Money Laundering and Counter-Terrorist Financing Ordinance (AMLO), Cap 615, Drug Trafficking (Recovery of Proceeds) Ordinance (DTROPO), Cap 405, Organized and Serious Crimes Ordinance (OSCO), Cap 455, and, United Nations (Anti-Terrorism Measures) (Amendment) Ordinance 2018; for details: Hong Kong Companies Registry, AML/CFT Legislation <www.cr.gov.hk/en/amlctf/ legislation.htm>.

${ }_{91}$ Under the UNSO, Hong Kong also made the Weapons of Mass Destruction (Control of Provision of Services) Ordinance (Chapter 526) (WMD(CPS)O), the United Nations Sanctions (Democratic People's Republic of Korea) Regulation (Chapter 537AE) and the United Nations Sanctions (Joint Comprehensive Plan of Action-Iran) Regulation (Chapter 537BV). For more details, see 'Hong Kong Money Laundering and Terrorist Financing Risk Assessment Report' (April 2018) 9-12<www.fstb.gov .hk/fsb/aml/en/doc/hk-risk-assessment-report_e.pdf>.

92 The Security Bureau maintains lists of designated individuals and entities under the UNATMO The United Nations (Anti-Terrorism Measures) Ordinance (Cap 575). 
UNSCRs are unlawful under Hong Kong law, financial institutions in practice enforce both UNSC and US/EU unilateral sanctions..$^{93}$ An interesting question is therefore how to deal with those 'violations' of unilateral sanctions, for example, Syrian payments through Russian banks under US unilateral sanctions. The legal practice in Hong Kong is that the bank might ask the account holder for further explanations, when there is a low tipping-off risk, and report it to the Financial Intelligence Unit and internally label the account with a red flag, while the suspected money would be declined and returned. Second, the bank would close the account, if there were any repeated suspected violations. The logic is that the bank could end the service contract with its client if there is ground to believe the bank account is being used for any unlawful activities. ${ }^{94}$ Third, the administrative agencies would make further investigations based on suspected transaction reports or other intelligence, which might lead to the deregistration of the company's legal personality in Hong Kong. ${ }^{95}$ This is particularly the case of shell or front shipping companies associated with the DPRK under US designations. ${ }^{96}$ It explains why, of the 182 sanctions violations Police and Customs investigated last year, 'no cases resulted in charges as government deregistered suspect companies or denied suspicious ships entry'. ${ }^{97}$ Another concrete example of the tension is that in the bond and equity primary market, Chinese issuers shall not use any capital raised for any purpose for the benefit of Russia.

Turning to remedies and procedures, we will use the same categories as in Section 4. Where administrative remedies are concerned, Hong Kong runs an administrative petition mechanism for individuals or entities with de-listing clarification requests. As C\&ED is in charge of the overall sanctions, it serves as the main focal point for handling specific requests to clarify the accuracy of sanctions information and to state reasons for sanctions including asset freezing. ${ }^{98}$

93 See Section 2 of this chapter, especially (n 27).

94 See for example 'by signing this application form, you [customers] agree that we [the HSBC Group] may use and disclose all personal data about you ... for the purposes ... within and outside Hong Kong in order that we comply with ... obligations according to local or foreign laws, regulations, judgments or court orders including those that relate to Unlawful Activities ... [including] money laundering, terrorist financing, bribery, corruption, tax evasion, fraud or sanctions'. Declaration, Integrated Account - Investment Services application form, Page 4, HSBC Hong Kong <https://cdn.hsbc.com.hk/content/ $\mathrm{dam} / \mathrm{hsbc} / \mathrm{hk} / \mathrm{docs} /$ accounts/personal-integrated/investment-services-application-form.pdf $>$ accessed 28 June 2020.

95 For example, Skycom, the alleged shell company registered in Hong Kong, controlled by Ms Meng Wanzhou, Huawei's CFO, was voluntarily deregistered. There might be both voluntary and forceful deregistration. Voluntary deregistration might be made because the life of a company had in practice ended when all banks closed any of its accounts and stopped any money transfer to and from that company. Forceful 'voluntary' deregistration is also possible in sanctions or money laundering cases like those through shipping companies, for fear of the disciplinary powers of the Hong Kong Registrar of Companies (including a power 'to order the licensee to take, by a date specified by the Registrar, any action specified by the Registrar'), as stipulated by section 53Z of the AMLO, as well as by Guideline on Imposition of Pecuniary Penalty, pursuant to section 53ZB(1), AMLO <www.tcsp.cr.gov.hk/tcspls/ portal/guide/61/eng?view $=1>$.

96 Treasury Announces Largest North Korean Sanctions Package Targeting 56 Shipping and Trading Companies and Vessels to Further Isolate Rogue Regime (23 February 2018) <https://home.treasury .gov/news/featured-stories/treasury-announces-largest-north-korean-sanctions-package-targeting-56>. See also (n 34 and 35).

97 (n 25).

98 'False Positives: Individuals or entities affected by targeted financial sanctions as a result of mistaken identification or confusion with individuals or entities on the above Sanctions Lists may submit written requests for clarification to the Commerce, Industry and Tourism Branch of the Commerce 
As there is no autonomous sanctions regime there, it is unlikely that such a response would lead to a judicial review in the Hong Kong courts.

Turning to judicial review over AML/CFT/CFP disciplinary actions, the HKMA and the SFC, which work as financial sanctions law enforcement agencies in Hong Kong, ${ }^{99}$ could take any necessary disciplinary action against local branches of global banks ${ }^{100}$ and non-bank financial institutions. ${ }^{101}$ Any of these agencies' acts can be challenged before the Anti-Money Laundering and Counter-Terrorist Financing Review Tribunal ${ }^{102}$ as well as by judicial review in the court system. ${ }^{103}$ Moreover, for financial institutions in Hong Kong, there is no 'discount' on sanctions enforcement fines or settlements as is available from the US law enforcement agency. ${ }^{104}$ It is relatively common ${ }^{105}$ for listed companies in Hong Kong ${ }^{106}$ to request the judicial review of the financial regulators' acts, which would not jeopardize the court decision over the related legal disputes. ${ }^{107}$

and Economic Development Bureau, after requesting an explanation from the institution that froze the assets, including a request that they identify which individual or entity on the Sanctions Lists forms the basis for the freezing action'. C\&ED Bureau of HKSAR Government < www.cedb.gov.hk/citb/en/Policy _Responsibilities/united_nations_sanctions.html $>$.

99 AMLO, 54. Interpretation of Part 6, specified authority.

100 HKMA AML/CFT Disciplinary Actions, including JPMorgan Chase Bank, National Association, Hong Kong Branch, Shanghai Commercial Bank Limited, Coutts \& Co AG, Hong Kong Branch, and State Bank of India, Hong Kong Branch <www.hkma.gov.hk/eng/key-functions/banking/anti-money -laundering-and-counter-financing-of-terrorism/disciplinary-actions/> accessed 28 May 2020.

$101 \mathrm{SFC}$ AML/CFT rules and standards <www.sfc.hk/web/EN/rules-and-standards/anti-money -laundering-and-counter-terrorist-financing/>; SFC AML/CFT enforcement, for example, on Southwest Securities (HK) Brokerage Limited and BMI Securities Limited in $2020<$ www.sfc.hk/edistributionWeb/ gateway/EN/news-and-announcements/news/enforcement-news/>.

102 AMLO, Part 6: Anti-Money Laundering and Counter-Terrorist Financing Review Tribunal (amended in 2018).

103 ibid, Part 6, Division 3 - Appeals to Court of Appeal; to date, however, there have been no sanctions cases.

104 (nn 11-13).

105 There are in total 252 cases involving SFC in the Hong Kong Court of First Instance (HKCFI) from 1991 to May 2020, 212 of which were filed after the Securities and Futures Ordinance, Cap 571 ('the SFO') was enacted in March 2002. On average there are 12 cases with SFC every year. Source of data: Hong Kong Legal Information Institute (HKLII) <www.hklii.org/> accessed 28 May 2020.

106 Including those companies registered in foreign jurisdictions but listed on the Hong Kong stock exchange as consented by the exchange as well as the SFC.

107 See for example Cheung Ka Ho Cyril \& Ors v SFC [2020] HKCFI 270: Hong Kong High Court Dismisses Judicial Review Challenging the SFC's Investigative Powers (11 March 2020) $<$ www.debevoise.com/insights/publications/2020/03/hong-kong-high-court-dismisses-judicial-review>; Waddington Ltd v SFC [2018] HKCFI 2544: Judicial review against the SFC's decision in relation to statutory investigation <www.onc.hk/en_US/judicial-review-sfcs-decision-relation-statutory -investigation/>; To Man Choy Jacky v SFC [2020] HKCFI 270: Hong Kong Court Rejects Legal and Constitutional Challenges to Securities and Futures Commission Investigative Powers $<\mathrm{https} / / \mathrm{dipp}$ ingthroughgeometries.blog/2020/03/18/hong-kong-court-rejects-legal-and-constitutional-challenges-to -securities-and-futures-commission-investigative-powers/>. 


\section{CONCLUSION}

Through a series of first-hand fieldwork investigations and a review of judicial cases in the local courts, this chapter completes the first empirical analysis of transnational legal orders of unilateral extraterritorial sanctions in Mainland China, Hong Kong and Macau. These three legal jurisdictions of China show the very different levels of influence foreign unilateral sanctions have in its domestic/local legal orders. The chapter also presents a variety of judicial and non-judicial remedies and procedures (or even the absence of procedures for some cases in Macau) for unilateral sanctions-related disputes, and how all three jurisdictions run a legal order of sanctions law enforcement, predominantly through their administrative agencies in the executive branch. It also finds that even in these legal orders dominated by the executive branch, the main remedies against a specific administrative decision, enforcement or fine for AML/CFT/CFP or sanctions violations are varied: in Mainland China, they are administrative reconsideration and complaint; in Hong Kong, it is largely by a simple request for sanctions information clarification and reasons; and, in Macau, such remedies are not available in practice as illustrated by the Bank Delta Asia case. All in all, this chapter has provided a concrete analysis of the relevant procedures that are of interest to any economic operator acting in China including Hong Kong and Macau, when its activities there are affected by foreign unilateral and extraterritorial sanctions.

\section{NOTE}

This is an open access work distributed under the Creative Commons Attributio n-NonCommercial-NoDerivatives 4.0 Unported (https://creativecommons.org/licenses/by-nc -nd/4.0/). Users can redistribute the work for non-commercial purposes, as long as it is passed along unchanged and in whole, as detailed in the License. Edward Elgar Publishing Ltd must be clearly credited as the owner of the original work. Any translation or adaptation of the original content requires the written authorization of Edward Elgar Publishing Ltd. 